\title{
10
}

\section{The Goods and Services Tax (GST): The public value of a contested reform}

\author{
Binh Tran-Nam
}

We particularly had in mind whether the time had come to shift a greater burden of the revenue raising effort towards general consumption taxes, thus enabling reductions in personal income tax.

— John Howard, Treasurer (1981: 758)

Never ever. It's dead.

— John Howard, Leader of the Opposition, 1995

\section{Introduction}

Modern governments require resources to provide essential goods and services, build infrastructure, make transfer payments (such as aged pensions and cash subsidies to businesses) and make interest payments on government debt. Governments can potentially derive their revenue from many different sources, such as tax collection, operating surpluses of government-owned enterprises, revenue from natural resources and investment returns from sovereign wealth funds. Taxation-as a process of transferring resources from the private sector to the public sectorrepresents by far the most important source of government revenue in 
most countries around the world. In the 2016-17 fiscal year, tax revenue constituted almost 94 per cent of total revenue of the general government sector in Australia (Commonwealth of Australia 2018: Table 1).

The tax system is not just a means of raising revenue to finance government spending; it also plays an important role in people's lives. It significantly influences the welfare of citizens and the development of society through its impact on the allocation of resources, stabilisation of the macroeconomy and redistribution of income and wealth.

Australia has undergone significant tax changes in the past 35 years. An example is the base-broadening income tax reform by the Hawke Labor Government, including the capital gains tax and fringe benefits tax, introduced in 1985 and 1986, respectively. Accompanying this base broadening was a reduction in income tax rates. In recent years, proposed tax reforms have held a priority position on Australia’s political agenda.

However, no tax change has been as major and dramatic as the introduction of the goods and services tax (GST) by the Howard Coalition Government to replace the wholesale sales tax (WST) and a number of state taxes with effect from 1 July 2000. The GST, or value-added tax (VAT) as it is known in Europe and Japan, is an indirect tax (a sales tax levied on the purchase of goods and services). It is broad based as it is applied to most goods and services and imposed on all stages of the production and distribution processes. The GST is assessed incrementally on the value added (increase in value) of a good or service at each stage of the supply chain. ${ }^{1}$ It is a tax imposed on domestic consumption, including imports but not exports. ${ }^{2}$

The Australian GST reform is more accurately described as a GSTbased reform, although, for convenience, both GST reform and GSTbased reform are employed interchangeably in this chapter. The reform involved four key elements: 1) the replacement of the federal WST

1 Thus, the GST is an ad valorem tax in the sense that it is calculated on the basis of the value of goods or services sold.

2 Further, a GST is normally taxed in the country where the private consumption ultimately takes place. This is known as the destination principle of taxation. The complexity of any GST system arises in the form of zero-rated and exempt supplies. The supplier of zero-rated (or GST-free) supplies (for example, exports or some food items) is not required to charge output GST but is entitled to claim back input GST paid. The supplier of an exempt supply (for example, financial services, educational services, residential accommodation) is not required to charge output GST but cannot claim back input GST paid. Another complication is that, in many countries but not Australia, there are many GST rates (one standard rate plus one or more reduced rates for essential goods). 
and a range of state indirect taxes with the GST; 2) a comprehensive compensation package for the perceived 'losers' from the introduction of the GST; 3) a series of subsequent direct tax cuts, at both company and individual levels; and 4) reform of Commonwealth-state financial relations. This is why the federal Coalition Government described the GST-based reform not as a new tax, but as 'a new tax system' (Department of the Treasury 1998).

The GST model was first implemented in France in 1954. The modern model of the GST with a broad base and single rate (with which Australians are familiar) was introduced in New Zealand in 1984. In terms of the technical design and implementation of the GST, Australia was a slow follower, not a world leader. What distinguishes the Australian GST-based reform are the comprehensive compensation package and the innovative use of the GST to modernise the financial relations between the Commonwealth and state and territory governments.

\section{The GST as a public policy success}

The introduction of the GST can be regarded as a genuine tax reform that produced change for the better, albeit not with complete success. In programmatic terms, there is a well-developed and empirically feasible public value proposition that underpins the reform of the taxation system. The changes sought to stimulate economic growth and development by securing increased government revenue, enhancing business prosperity, stimulating greater investment and encouraging increased exporting (Department of the Treasury 1998: 14-15). The intent was to replace the outdated, inefficient and distorted system of state and federal indirect taxes with a new tax system that was fairer, simpler and more rewarding for individuals (Department of the Treasury 1998: 3-16). To achieve such ends, the means was a broad-based consumption tax (BBCT), preferably with a single rate. Among the menu of feasible alternatives, the Howard Government chose the GST as an appropriate policy instrument.

In terms of a theory of change, the GST is flexible enough to enable incremental adjustments to address changing conditions. For example, if Australian economic conditions require a greater amount of tax revenue to be raised from household consumption, it is possible to expand the GST base and/or raise the GST standard rate to more than the current rate of 10 per cent. Similarly, if the Australian macroeconomy calls for 
much less tax revenue to be raised from consumption, the GST rate can be reduced to less than 10 per cent. In practice, however, there are some legal and political constraints to such changes, thus reducing the flexibility of the GST as a tax policy instrument. This will be discussed further later in this chapter.

In process terms, the GST reform exhibited thoughtful and effective design and policymaking practices. The problem with Australia's indirect tax system, particularly the WST, lay in its narrow base and multiple tax rates. As a policy instrument, the GST followed the mantra from the previous Keating-era reforms of income tax: broaden the base and lower the rate. The choice of a broad-based, single-rate GST as the indirect tax reform measure in 1998 brought Australia into line with countries such as New Zealand. All tax reforms typically give rise to winners and losers and the GST proposal was accompanied by a comprehensive compensation package to smooth its passage (Department of the Treasury 1998: 16-19). Also, it was accompanied by substantial income tax cuts following its implementation. For example, the company income tax rate decreased from 34 per cent to 30 per cent in 2000-01. Similarly, the top individual income tax rate was reduced from 47 per cent in 1990-91 to 45 per cent in 2006-07, whereas personal income tax brackets have been enlarged (the tax-free threshold from $\$ 4,594$ in $1985-86$ to $\$ 6,000$ in 2011-12, and then markedly to $\$ 18,200$ in 2012-13); and taxable income thresholds for the top tax rate have been raised (from $\$ 50,000$ in $1989-90$ to $\$ 60,000$ in $2000-01, \$ 70,000$ in $2004-05$ and then markedly to $\$ 180,000$ in $2008-09)$.

In rolling out the GST, the Howard Government had the advantage of inheriting the required administrative and technical details to implement the GST from John Hewson's revised 'Fightback!' package (Liberal Party of Australia 1991). The Australian Taxation Office (ATO) was given sufficient additional resources to cope with the administrative challenges of introducing the new system from 1998 to 2001 (D'Ascenzo 2005). The two-year gap between announcement and commencement allowed adequate time for the private sector to prepare for the implementation of the GST. The 'education first, enforcement later' approach adopted by the ATO resulted in a smooth implementation process with high levels of ongoing compliance. The timing of the GST was particularly helped by the strengthening of the Australian economy in the years leading up to 2001 . 
In political terms, the GST-based tax reform passes the test of public policy legitimacy. Howard and his government took a considerable risk in promoting a GST as the centrepiece of their reelection platform-a move described as a 'bold attempt to remedy long-acknowledged deficiencies in the system' (The Age 1998: 12). Howard's admittedly narrow 1998 electoral victory gave his government a historic mandate for indirect taxation reform. The broad public acceptance of the new tax system was quite remarkable considering the overwhelming public rejection a similar proposal had received just five years earlier. However, the legitimacy of the GST was somewhat diminished by the Treasury's attempt to portray the tax as a state tax in the early years after its introduction; but, as the GST revenue is distributed to the states under the previously mentioned intergovernmental agreement, the states have received stable and growing financial support from the Commonwealth and thus have been supportive of the measure once it was in place. ${ }^{3}$

Tax reform is an ongoing process. In terms of endurance, the GST has become a major part of Australia's tax system and appears likely to stay in place well into the future. Since its adoption, there have been only minor changes to the GST legislation. However, in terms of financial sustainability, the GST cannot be termed a 'great policy success'. Although the GST is a stable and growing source of revenue, its durability has often been questioned. This is because GST-exempt goods and services have increased more than the actual GST base. The GST base has shrunk over time as a percentage of household final consumption expenditure. To halt the erosion of indirect tax revenue, adjustments will need to be made to the base of the GST. There are, however, legal and political constraints to either changing the standard GST rate or expanding the GST tax base. These issues will be further discussed later in this chapter.

In sum, the GST is widely perceived as a policy success by various stakeholders, including tax academics and researchers, businesses and professional organisations and international organisations such as the OECD. Other countries have struggled to implement a GST as smoothly or successfully as Australia. For example, the introduction of the Canadian GST in 1991 was hampered by poor timing (the economy was in recession) and a lack of transparency and political legitimacy. Australia's

3 There are still Commonwealth-state disputes about the allocation of total GST revenue, as discussed later. 
experience was much different. The core of Australia's GST success lies in the intended consequences that the Howard Government deliberately sought to achieve.

\section{Distributional effects}

These positive effects aside, the GST-based reform has not achieved or, more accurately, cannot achieve some of its specific objectives-namely, a simpler and fairer tax system. This is largely because it is a complex and regressive tax. The GST is a complex tax because: 1) its operation involves a very large number of registered businesses and tax administrators (compared with a revenue-equivalent WST);2) registered businesses act as tax collectors on behalf of the government; 3) under the Australian method of calculation, the GST is a transaction-based method imposed on every sale; and 4) it is not legally simple. There is unambiguous evidence that the GST is by far the most burdensome tax with which small and medium businesses in Australia have to comply (Lignier et al. 2014: 239).

The distributional costs and benefits of the GST-based reform to Australians include a higher indirect tax burden and a lower income tax burden, respectively. Like most tax changes, the GST-based reform gave rise to winners and losers. Certain individuals, or groups of individuals, have been disproportionately affected by the changes. In the first group are low-income individuals who spend a high proportion of their income on consumption and pay little in income tax. The second group consists of older individuals who paid high income tax when they were young and are now facing higher indirect tax burdens. The second group appeared to be adequately compensated as there was a one-off 4 per cent increase in aged and service pensions under the new system (Department of the Treasury 1998: 18), whereas the one-off increase in the rate of inflation due to the GST was estimated to be about 2.8 per cent across Australia (Valadkhani and Layton 2004: 125).

Despite this compensation, a gap remains between people's absolute and relative levels of wellbeing. The distributional impact of the GST, as an indirect tax, is regressive in the sense that the GST burden relative to income declines as income becomes higher. Further, the distributional impact of income tax cuts is also regressive in the sense that income tax reduction relative to income tends to increase as income becomes higher. The combined distributional impacts of the GST and accompanying income tax cuts thus reduce the overall progressivity of the Australian 
tax system. This results in an increase in post-tax income inequality, which in turn implies that the GST-based reform cannot produce a fairer distribution of tax burdens.

Table 10.1 summarises several groups of winners and losers created through the introduction of the GST.

Table 10.1 Winners and losers as a result of the introduction of the GST

\begin{tabular}{|l|l|l|l|}
\hline \multicolumn{2}{|c|}{ Winners } & \multicolumn{2}{c|}{ Losers } \\
\hline $\begin{array}{l}\text { Large } \\
\text { businesses }\end{array}$ & $\begin{array}{l}\text { Less distortionary } \\
\text { taxation, lower company } \\
\text { tax rate, promotes } \\
\text { exports, cash flow } \\
\text { benefits }\end{array}$ & $\begin{array}{l}\text { Small } \\
\text { businesses }\end{array}$ & $\begin{array}{l}\text { GST compliance costs are } \\
\text { higher than managerial } \\
\text { benefits }\end{array}$ \\
\hline $\begin{array}{l}\text { High-income } \\
\text { individuals }\end{array}$ & $\begin{array}{l}\text { Overcompensated by } \\
\text { income tax cuts }\end{array}$ & $\begin{array}{l}\text { Very low- } \\
\text { income } \\
\text { individuals }\end{array}$ & $\begin{array}{l}\text { Even if they are fully } \\
\text { compensated, they are } \\
\text { worse off relative to } \\
\text { higher-income individuals }\end{array}$ \\
\hline $\begin{array}{l}\text { State and } \\
\text { territory } \\
\text { governments }\end{array}$ & $\begin{array}{l}\text { Certain and growing } \\
\text { financial support from the } \\
\text { Commonwealth }\end{array}$ & & \\
\hline
\end{tabular}

\section{Context: A reform rooted in history}

To comprehend the rise of the GST in Australia, we need to understand the historical basis and structure of the Australian tax system, especially during the 1990s. This section focuses on the two most relevant features leading to the introduction of the GST: Commonwealth-state financial relations and tax structure.

\section{Commonwealth-state financial relations}

As noted by many political scientists, the Australian Constitution is deliberately vague on the allocation of taxation powers between the Commonwealth and the states in view of the political sensitivity of this issue at the time of Federation (see, for example, Eccleston 2007: 68). Prior to Federation, several colonies had introduced general income taxesfor example, South Australia in 1884 and New South Wales in 1885. Comprehensive corporate and personal income taxation was introduced by the Commonwealth in 1915 to help fund Australia's effort in World War I. For almost three decades, income taxes were imposed by both the Commonwealth and the states. 
In 1942, at the height of World War II, the federal Labor Government passed laws to raise the federal income tax rate and return some of the proceeds back to the states on the condition that all states abolished their income taxes. Four states-Queensland, South Australia, Victoria and Western Australia—challenged the legislation in the High Court but lost. This is known as the Uniform Tax Case (1942). As a result of this significant centralisation of taxation power, an enduring situation of vertical fiscal imbalance developed in Australia; the states raised much less in revenue than the expenditures for which they were responsible, whereas the reverse situation existed for the Commonwealth.

Australia's vertical fiscal imbalance is the highest among all nations with federal systems of government (Garnaut and FitzGerald 2002: 291). As a result, Australian states have relied significantly on Commonwealth grants to fund their expenditure. There are two types of Commonwealth transfers to the states: general purpose payments and specific purpose payments (tied grants). These grants are provided to the states under the principle of horizontal fiscal equalisation, introduced in 1933, which distributes more funds to those states and territories that have a lower capacity to raise revenue or have a greater cost burden.

This structural feature has been a constant source of friction between the Commonwealth and the states. It forces the states to rely on narrow-based taxes (for example, stamp duties) for their own-source revenue. This has been exacerbated by the High Court's increasingly broad interpretation of the Australian Constitution in regard to customs, excise and bounties. Most relevantly, in Ngo Ngo Ha and Anor vs State of NSW \& Ors (1997) HCA 34, the court ruled by a slim majority that state tobacco franchise fees were an excise-a tax constitutionally reserved for the Commonwealth. While the decision brought some clarity to a confusing area, it further exacerbated the impact of the vertical fiscal imbalance in Australia.

\section{Tax structure}

In terms of structure, the Australian tax system has become highly reliant on direct taxation, particularly personal income taxation. Towards the end of the twentieth century, about three-quarters of Commonwealth revenue was derived from direct taxation, with a little over half of it from individual income taxes (OECD 1997). Australia's personal income taxation in the early 1980s had a narrow base due to the many exemptions and deductions, but also as a result of judicial rulings and 
legislative inaction (Krever 1986: 349). This resulted in the application of high marginal income tax rates at relatively low levels of income and widespread tax avoidance and evasion (Freebairn 2005: 3). The legitimacy of the income tax system was increasingly called into question as wage earners faced rising tax burdens while growing numbers of professional and self-employed taxpayers were successfully evading or avoiding income tax (Eccleston 2007: 70).

During the same period, Australia's indirect tax system appeared to suffer the problems associated with having a narrow base. Australia's first general consumption tax, the WST, was introduced in 1930 to raise additional revenue, largely to counter the significant budget deficits arising from the onset of the Great Depression. It was a single-stage consumption tax levied on a wide range of nonessential goods, initially at the uniform rate of 2.5 per cent. The WST gradually grew into a cumbersome tax with a narrow base (the wholesale of goods), a multiple rate structure and a cascading effect on production. By 1995, the share of private consumption subject to the WST fell to 22 per cent and there were six different rates, not counting the zero rate that applied to excluded items (Reinhardt and Steel 2006: Table 2).

In summary, states' and territories' financial dependence on the Commonwealth, high marginal individual income tax rates at relatively low levels of income and the outdated and inadequate WST all served as the background for indirect tax reform in Australia.

\section{Design and choice: Getting the GST across the line}

\section{Trials and failures}

While the need to reform the WST was apparent, it took 25 years and many failed attempts for the WST (and several indirect state taxes) to be replaced with the GST. The first call for a BBCT was made in the Asprey Report more than two decades before reform occurred (Commonwealth Taxation Review Committee and Asprey 1975). However, the then newly elected Labor Government did not make any reference to a BBCT in its 1975 budget. 
In February 1982, then treasurer John Howard made a submission to the Coalition Cabinet proposing a BBCT, with a number of options. While his proposal was rejected by the Cabinet, he persisted and later wrote:

I have long believed that the single most important reform which is needed to the Australian taxation system is the broadening of the taxation base towards a greater reliance on general consumption taxes with a corresponding reduction in our current over-reliance on personal taxation as a source of revenue. (Howard 1984: 12)

In the closing chapter of a $1985 \mathrm{draft}$ white paper (Department of the Treasury 1985), treasurer Paul Keating proposed a BBCT under 'Option C' (a 12.5 per cent broad-based retail sales tax ${ }^{4}$ plus major personal income tax cuts) or 'Option B' (a 5 per cent broad-based retail sales tax plus modest personal income tax cuts). Both options $\mathrm{B}$ and $\mathrm{C}$ were rejected at the National Taxation Summit (1985), due mainly to the lack of support from the Australian Council of Trade Unions (ACTU) and welfare and business lobby groups.

The GST (with a broad base and a proposed standard rate of 15 per cent) then resurfaced, as the central element of John Hewson's 'Fightback!' package (Liberal Party of Australia 1991), which cost the Liberals the 1993 federal election. Immediately after the 1993 debacle, Howard ruled out a GST as part of the Coalition's policy for the next federal election, in 1996. In fact, he made a politically expedient commitment in 1995 'never ever to introduce a GST’ (Megalogenis 1999: 99).

\section{The GST returns}

The Coalition under Howard's leadership enjoyed a landslide victory in the 1996 federal election. However, in the 12 months following the Coalition's return to office, Howard suffered a dramatic reversal in political fortune and his approval rating as preferred prime minister fell to 20 per cent (Aubin 1999: 216). Despite his own 1995 commitment, he was under pressure from many quarters, especially senior members of the business community, to proceed with an indirect tax reform (Eccleston 2007: 79).

4 A retail sales tax is imposed at the retail level (that is, from business to individual/household). A broad-based retail sales tax is roughly equivalent to a GST (with the same rate) in terms of revenue; however, a retail sales tax is simpler but more prone to evasion than a GST. 
In the meantime, there were many signs of changing perceptions in the GST debate. First, Keating's political triumph at the 1993 election turned out to be short-lived. With tax revenue growth failing to meet expectations, the Keating Government could not deliver on its election promise of income tax cuts without raising indirect taxes. This government failure and the resulting increase in the WST and excises in the 1993-94 Budget cast a new and favourable light on the much-criticised GST.

Second, traditionally, the GST was favoured by business organisations and opposed by key welfare groups. A change in community attitudes towards the GST became apparent at a national tax summit hosted jointly by the Australian Chamber of Commerce and Industry and the Australian Council of Social Service (ACOSS) in 1996. At the meeting, both organisations broadly agreed on an indirect tax reform accompanied by compensating welfare benefits. There was also broad support for a GST from state premiers and a diverse range of bodies such as CPA Australia, the National Commission of Audit and the Productivity Commission (Harrison 1999). Third, there was the 1997 High Court decision that struck down state franchise taxes (or excises more generally) on constitutional grounds - paving the way for the GST, at least from the states' perspective.

This changing tide in the GST debate allowed Howard to seize the opportunity by taking steps to formulate a tax reform package that the majority of Australians could endorse (Eccleston 2007: 79). In designing a tax reform package that would determine the fate of his government, Howard was greatly assisted by his treasurer, Peter Costello. After a year of intense debate and speculation, the proposed new system was released in 1998.

This proposal foreshadowed the replacement of the WST with a comprehensive GST, with food in its base and a standard rate of 10 per cent. The proposed GST was projected to raise $\$ 27.2$ billion in revenue in the first year (2000-01). The package also included social security and family assistance reforms (including a one-off 4 per cent increase across the board in social security payments) to compensate potential losers, substantial personal income tax cuts and changes to business taxation. Another essential element of the new system was the link between the GST and fiscal federalism. The package proposed to allocate all GST revenue to state governments as general-purpose grants (via the Commonwealth Grants Commission mechanism), provided they abolished certain indirect state taxes. 
The comprehensive tax base of the proposed GST followed the New Zealand model. Its standard rate was kept low, at 10 per cent (compared with the standard rate of 15 per cent proposed in the 'Fightback!' package) to satisfy business demands while the increase in social security payments made the model acceptable to the welfare sector. The income tax cuts reflected Howard's personal view that his reelection depended heavily on middle-income earners who would favour such changes to the tax mix. Clearly, the novel and least anticipated feature of the new system was the restructuring of Commonwealth-state financial relations. As something of a master stroke, this ensured support from the states, which had been looking for a stable and growing source of unconditional transfers from the Commonwealth.

The reelection of the Howard Government in October 1998 on the platform of a new tax system-albeit with a swing against it ${ }^{5}$-was unprecedented in Australian federal history. No political party had ever been elected on a platform of a major new tax before. However, to achieve passage of the GST Bill through parliament, the government found it necessary to make several compromises with the Australian Democrats, who controlled the balance of power in the Senate. ${ }^{6}$ These compromises narrowed the base of the GST that was initially proposed; the most notable change was the removal of fresh food, health services, medicines and education services from the GST base.

Even after the compromise had been struck, there was internal opposition against the modified GST within the Australian Democrats. This was evident when three Democrats senators crossed the floor and voted against the GST that their leader had successfully negotiated. (This would later lead to infighting and the eventual demise of the Australian Democrats as a political force). Thus, without the Australian Democrats' compromise, the GST would not have been passed by the Senate and another period of policy paralysis might have ensued.

The ALP opposed the GST when it was proposed by the Coalition at three federal elections, in 1993, 1998 and 2001. In 1993, using his political skills and experience as a former treasurer, prime minister

5 The Howard Government suffered a swing of 4.61 per cent against it and achieved a two-party preferred vote of only 49.02 per cent, compared with Labor's 50.98 per cent.

6 As a result of the GST negotiation between Australian Democrats leader Meg Lees and John Howard, the Australian Democrats split and were eventually annihilated following the 2007 federal election. 
Keating defeated the Hewson-led Coalition and its 'Fightback!' agenda, despite the fact the Treasury under Keating's leadership had proposed a BBCT at the National Tax Summit eight years earlier. Subsequently, as opposition leader, ALP's Kim Beazley fought against the new tax system and narrowly lost the 1998 election. During the 2001 campaign, Beazley continued to oppose the GST, making a vague 'GST rollback' part of his election platform. The ALP's loss of the 2001 election $^{7}$ effectively ended any serious opposition to the GST in Australia.

\section{The implementation experience}

The amended GST was enacted on 28 June 1999 as A New Tax System (Goods and Services Tax) Act 1999 (Cwlth). It gained assent on 8 July 1999 and became effective from 1 July 2000. The subsequent implementation of the GST reform was relatively smooth. Several factors combined to help ease the transition:

- The Australian economy was performing strongly in 2000.

- The reform was well designed and the Howard Government obtained all necessary planning and coordination details for implementing the GST from the 1992 'Fightback!' package (see, for example, the unpublished report of the GST Planning and Co-ordination Office). ${ }^{8}$

- The compensation package was appropriate and acceptable to the welfare sector.

- The lag time between the announcement of the new system and the commencement of the GST provided businesses with ample time to prepare for its operation.

- The ATO efficiently handled the administration of the introduction of the GST.

While most of the above factors are self-explanatory, it is worth elaborating on the ATO's contribution to the smooth implementation of the GST in Australia.

7 The 2001 federal election turned out to be dominated by the 'Tampa incident' and border protection policy.

8 The unpublished report of the GST Planning and Co-ordination Office can be obtained from Michael Evans, who was the technical director in charge of the office in 1992-93. 


\section{The ATO steps up}

The GST was associated with several new administrative issues, such as the Australian Business Number, GST registration, the replacement of all previous tax collection mechanisms with the pay-as-you-go (PAYG) system and the Business Activity Statement for reporting GST and other taxes. The ATO's strategy involved a broad and comprehensive education campaign and assistance program before, during and after the changes. A new division called GST was established within the ATO (later renamed Indirect Tax). The ATO targeted, in particular, businesses that would be brought into the tax system for the first time (for example, education and charitable sectors) and those with less sophisticated accounting systems (for example, small businesses).

The ATO conducted an extensive and intensive awareness, education and compliance campaign for GST implementation (Commonwealth of Australia 2003: 28). This two-year program included 5,200 seminars and workshops, the distribution of 170 million publications, telephone hotlines that received approximately 8.2 million GST-related phone calls and a tax reform website that recorded over 286 million hits. In addition, the ATO also made more than 440,000 free advisory field visits and actioned over 143,000 written requests for technical advice on the GST (Commonwealth of Australia 2003: 30).

The government allocated $\$ 500$ million to assist small and medium enterprises, community organisations and education bodies to prepare for the GST (Commonwealth of Australia 2003: 33). This funding was administered by the GST Start-Up Assistance Office within the Treasury. As the major part of this assistance program, the Start-Up Assistance Office issued over 1.9 million $\$ 200$ direct assistance certificates to assist eligible small and medium enterprises with the cost of purchasing GSTrelated products and services (Commonwealth of Australia 2003: 33).

The smooth implementation of the GST does not mean there were no adverse consequences. In fact, the introduction of the GST was associated with many negative outcomes. Here, we highlight two aspects-namely, economic growth and business compliance costs. 


\section{Transition and compliance costs}

An examination of Australia's aggregate economic output reveals that the Australian economy experienced a sharp slowdown in the second half of 2000, which corresponded with the implementation period of the GST. Time-series data on GDP provided by the Australian Bureau of Statistics (ABS 2018) show the annual growth rate in Australia fell from 3.9 per cent in 1999-2000 to 2 per cent in 2000-01 (a relative decline of almost half). It is plausible that this slowdown was the result of a reduction in business profitability stemming from an inability to fully pass the GST on to consumers. However, this slowdown was only temporary, as the annual growth rate recovered to 3.9 per cent in 2001-02.

The compliance costs of implementing the GST refer to the resources expended by business taxpayers in their preparation to comply with the new requirements. A wide range of compliance cost estimates exist (for a summary of these, see Tran-Nam and Glover 2002: Table 1). The Australian Treasury offered a figure of $\$ 2.2$ billion, which represented the lowest estimate. Other estimates varied considerably, ranging from $\$ 2.6$ billion and $\$ 3.15$ billion to $\$ 15$ billion and $\$ 24$ billion (Tran-Nam 2000: 338). The lower-end estimates are, however, perceived to be more credible. The author's own estimate of $\$ 2.8$ billion indicates that implementation costs incurred by businesses represented more than 10 per cent of the initial estimate of GST revenue in 2000-01.

\section{Endurance: An entrenched reform?}

There have been many amendments to the GST legislation since its introduction. These changes have largely been incremental in nature given the significant legal obstacles that exist. Recently, there have been changes in response to the increasing importance of the digital economy, including the imposition of GST on digital products and services and on low-value imported goods.

In terms of endurance, the GST has had a mixed performance. It has become an established major tax and an integral part of the political landscape in Australia. However, from a temporal perspective, it cannot be regarded as a complete success. While there have been recent calls for its reform, there are legal and political obstacles that prevent such reforms taking place. Further, the allocation of GST revenue to the states is still problematic. 


\section{Financial sustainability}

As discussed above, because some goods and services are GST exempt, the base of the implemented GST was smaller than that originally proposed. Furthermore, the GST-free goods and services have grown more rapidly than the GST base. As a result, the base has shrunk over time as a percentage of household final consumption expenditure. According to Australia's Future Tax System Review Panel (2009: 273), the GST base taxes only 57 per cent of consumption.

Additionally, household final consumption expenditure has grown more slowly than household income because people are saving more and consuming less. Combining these two effects, GST revenue has been falling as a proportion of GDP. For example, in 2003-04, the GST take was 3.85 per cent of GDP, while by 2012, that figure had fallen to 3.15 per cent (ABS 2012: Table 8). To make matters worse, from the perspective of the Australian states, while GST revenue is forecast to grow at a slower rate than GDP, the expenditure required to maintain current levels of health, education and other social programs is likely to increase at a rate faster than GDP. This implies structural budget problems for state governments in the long term.

In view of such issues, a natural response would be to expand the GST base, to raise the standard rate or a combination of both. Many tax experts and commentators support GST reform that would result in a more comprehensive tax base with minimal exemptions, along the lines of the original 1998 proposal or the New Zealand model (which also has a higher standard rate). There are, however, also tax scholars who argue that the GST-free status of certain goods and services is critical to taxpayers' perceptions of fairness, which in turn encourages tax compliance (Walpole 2017: 242). The very recent removal of the 'tampon tax' from the GST base serves to illustrate this point.

There are several problems associated with base broadening and rate increases. First, there are legal and political problems, which will be further discussed in the next subsection. Second, as with the introduction of the GST, to be politically palatable, any base broadening or rate hike would need to be part of a revenue-neutral package that also contains income tax cuts and a rise in social security payments so that the overall tax burden remains essentially unchanged. 


\section{Obstacles to base and rate changes}

Any changes in the GST base or rate would require unanimous agreement from state and territory governments as per the authorising legislation, A New Tax System (Commonwealth-State Financial Arrangements) Act 1999. This requirement gives rise to both legal and political constraints in reforming the GST. Despite the GST being legally a federal tax, the Commonwealth Government cannot unilaterally expand its base or increase its rate without agreement from all state and territory governments. Politically, it would be very difficult for any state government to initiate GST revenue expansionary proposals without incurring severe public backlash. Under appropriate conditions and with sufficient political will, the Commonwealth Government could pass legislation that makes the GST a truly federal tax (that is, a tax whose base and rate can be unilaterally controlled and determined by the Commonwealth Government).

\section{Allocation of GST revenue to states}

As emphasised throughout this chapter, a revolutionary feature of the current Australian tax system is that the full amount of net GST revenue is made available to state and territory governments as unconditional grants via the Grants Commission. But this intergovernmental agreement has nothing to say about actual allocation of GST revenue to states. Not surprisingly, the distribution of GST revenue among the states and territories has been a source of friction between the Commonwealth and those states that receive less than 100 per cent of the GST collected from consumers in their states.

In August 2018, the leader of the ALP, Bill Shorten, made a commitment to enshrine the GST floor in law. Less than two months later, Prime Minister Scott Morrison responded by promising to legislate changes to GST distributions. The legislation is designed to guarantee that the GST share of any state will be no less than 75 per cent of GST revenue collected from that state. It is unclear whether the 75 per cent floor is acceptable to all states which receive less than 100 per cent due to horizontal fiscal equalisation. However, any deviation from the current distribution will see some states fare better than others. No legislation can change that. 


\section{Conclusion}

Tax reform is typically a slow process, fraught with difficulties and uncertainties. There are many stakeholders with conflicting views, motives and approaches who can drive tax reform down a long and winding path. The introduction of a major tax such as the GST requires many factors, including a favourable economic climate, a well-designed tax reform plan, a relatively low initial tax rate, an acceptable compensation package and the ability of those politicians who are sponsoring it to respond effectively to the prevailing public mood and the concerns of stakeholders. In the Australian case, this was complicated by the federal system and the nature of intergovernmental financial relations. While John Howard can rightfully be regarded as the founder of GST reform in Australia, many other political leaders - such as Paul Keating, John Hewson and Peter Costello, in their different roles and capacities - contributed significantly to the eventual emergence of the GST.

The introduction of the GST can be viewed as a public policy success. A coherent and empirically feasible public value proposition and theory of change underpinned its introduction. It has achieved its principle aims - a stable and growing revenue source and less distortionary taxation-but it has not achieved some of its specific objectives (for instance, a simpler and fairer tax system). The GST-based reform improves economic efficiency but reduces social equity. This simply reflects the inherent and well-known trade-offs of tax policy objectives and the fundamental difficulties faced by tax policymakers in choosing an appropriate instrument.

The GST reform can also be considered a public policy success in terms of stakeholder support and public legitimacy for the policy. The electoral success of the new tax system, which gave the Howard Government its mandate to reform the indirect tax regime, significantly enhanced his personal reputation, as well as the political capital of his Coalition Government.

Further, the GST can be considered a public policy success in terms of process assessment due to its appropriateness as a policy instrument, the firm political commitment of the Howard Government, its well thoughtout design, the adequate additional funding for the ATO, the realistic timeline for adjustment given to business taxpayers, the competent 
administrative capacity of the ATO and, importantly, the opportune timing of its introduction. As a result, the GST reform has achieved most of its intended outcomes with minimal costs and disruptions.

That said, the GST can reasonably be viewed as somewhat less successful in terms of its endurance over time. Of course, it remains in place and its permanence seems secure. However, in its current form, it cannot halt permanently the erosion of indirect tax revenue, which was articulated as a specific objective of Howard's new tax system and which lay the foundations for introducing the GST in the first place. Part of the initial attraction of Howard's proposal was the rigidity of the GST. Any changes to the GST base or rate require unanimous agreements from all state and territory governments. This imposes both legal and political constraints on adjusting the tax. Therefore, the ongoing endurance of the GST as a highly effective means of revenue generation will ultimately depend on the motivations and political will of leadership in Australia's Commonwealth Government and its state and territory governments.

\section{References}

Aubin, T. 1999. Peter Costello: A biography—The full and unauthorised story of a man who wants to be PM. Sydney: Harper Collins.

Australian Bureau of Statistics (ABS) 2012. Australian National Accounts. Canberra: ABS.

Australian Bureau of Statistics (ABS) 2018. 'Table 2: Expenditure of gross domestic product (GDP)—Chain volume measure.' In Australian National Accounts: National income, expenditure and product. Cat. No. 5206.0, June. Canberra: ABS. Available from: www.abs.gov.au/AUSSTATS/abs@.nsf/ DetailsPage/5206.0Jun\%202018?OpenDocument.

Australia's Future Tax System Review Panel 2009. Australia's Future Tax System: Report to the Treasurer. Canberra: Commonwealth of Australia.

Commonwealth of Australia 2003. 'Preliminary assessment of the impact of the new tax system.' Economic Roundup Autumn 2003. Canberra: Commonwealth of Australia.

Commonwealth of Australia 2018. 'Statement 5: Revenue.' In Budget Paper No. 1. Budget 2018-19. Canberra: Commonwealth of Australia. 
Commonwealth Taxation Review Committee and Asprey, K. W. 1975. Full Report. 31 January. Canberra: AGPS.

D'Ascenzo, M. 2005. 'Administration and tax reform.' Journal of the Australasian Tax Teachers Association 1(2): 25-37.

Department of the Treasury 1985. Reform of the Australian tax system. Draft White Paper. Canberra: AGPS.

Department of the Treasury 1998. Tax Reform: Not a new tax, a new tax systemThe Howard Government's plan for a new tax system. Canberra: AGPS.

Eccleston, R. G. 2007. Taxing Reforms: The politics of the consumption tax in Japan, the United States, Canada and Australia. Cheltenham, UK: Edward Elgar.

Freebairn, J. 2005. A comparison of alternative tax bases. Melbourne Institute Working Paper No. 11/05. Melbourne: Melbourne Institute of Applied Economic and Social Research.

Garnaut, R. and FitzGerald, V. 2002. 'Issues in Commonwealth-state funding.' Australian Economic Review 53(3): 290-300.

Harrison, J. 1999. The GST Debate. Canberra: Department of the Parliamentary Library.

Howard, J. W. 1981. House of Representatives, Debates, 12 March. Canberra: Parliament of Australia.

Howard, J. W. 1984. 'Taxation reform.' Australian Tax Forum 1(1): 8-15.

Krever, R. 1986. 'Tax reform in Australia: Base-broadening down under.' Canadian Tax Journal 34(2): 346-94.

Liberal Party of Australia 1991. Fightback! Taxation and expenditure reform for jobs and growth. Canberra: Liberal Party of Australia.

Lignier, P., Evans, C. and Tran-Nam, B. 2014. 'Tangled up in tape: The continuing plight of the small and medium enterprise sector.' Australian Tax Forum 29(2): 217-47.

Megalogenis, G. 1999. 'Tax triumph is a legacy lost.' In P. Kelly (ed.), Future Tense: Australia beyond the 1998 election. Sydney: Allen \& Unwin.

National Taxation Summit 1985. Record of Proceedings. Canberra: AGPS.

Organisation for Economic Co-operation and Development (OECD) 1997. Revenue Statistics 1965-1996. Paris: OECD Publishing. 
Reinhardt, S. and Steel, L. 2006. 'A brief history of Australia's tax system.' Economic Roundup Winter 2016. Canberra: Commonwealth of Australia.

The Age 1998. 'A tax revolution worthy of the name.' The Age, [Melbourne], 14 August.

Tran-Nam, B. 2000. 'The implementation costs of the GST in Australia: Concepts, preliminary estimates and implications.' Journal of Australian Taxation 3: 331-43.

Tran-Nam, B. and Glover, J. 2002. 'Estimating the transitional compliance costs of the GST in Australia: A case study approach.' Australian Tax Forum 17(4): 499-536.

Valadkhani, A. and Layton, A. P. 2004. 'Quantifying the effect of GST on inflation in Australia's capital cities: An intervention analysis.' Australian Economic Review 37(2): 125-38.

Walpole, M. 2017. 'Exclusions from a GST: The arguments in favour of their preservation.' In The Australian Taxation System: The 2017 great debate. Sydney: Australian Tax Research Foundation. 
This text is taken from Successful Public Policy: Lessons from Australia and New Zealand, edited by Joannah Luetjens, Michael Mintrom and Paul 't Hart, published 2019 by ANU Press, The Australian National University, Canberra, Australia.

doi.org/10.22459/SPP.2019.10 